\title{
Genome sequence and description of Corynebacterium ihumii sp. nov.
}

\author{
Roshan Padmanabhan ${ }^{1}$, Grégory Dubourg ${ }^{1}$, Jean-Christophe Lagier ${ }^{1}$, Carine Couderc ${ }^{1}$, Caro- \\ line Michelle ${ }^{1}$, Didier Raoult ${ }^{1,2}$ and Pierre-Edouard Fournier ${ }^{1 *}$ \\ 'URMITE, UM63, CNRS7278, IRD198, Inserm1095, IHU Méditerranée-Infection, Aix- \\ Marseille Université, Faculté de médecine, France \\ ${ }^{2}$ Special Unit Agents, King Fahd Medical Research Center, King Abdul Aziz University, Jed- \\ dah, Saudi Arabia \\ *Correspondence: Pierre-Edouard Fournier (pierre-edouard.fournier@univ-amu.fr) \\ Keywords: Corynebacterium ihumii, genome, culturomics, taxono-genomics
}

Corynebacterium ihumii strain GD7 $7^{\top}$ sp. nov. is proposed as the type strain of a new species,
which belongs to the family Corynebacteriaceae of the class Actinobacteria. This strain was
isolated from the fecal flora of a 62 year-old male patient, as a part of the culturomics study.
_Corynebacterium ihumii is a Gram positive, facultativly anaerobic, nonsporulating bacillus.
Here, we describe the features of this organism, together with the high quality draft genome
sequence, annotation and the comparison with other member of the genus Corynebacteria.
C. ihumii genome is 2,232,265 bp long (one chromosome but no plasmid) containing 2,125
protein-coding and 53 RNA genes, including $4 \mathrm{rRNA}$ genes. The whole-genome shotgun se-
quence of _Corynebacterium ihumii strain GD7 ${ }^{\top} \mathrm{sp}$. nov has been deposited in EMBL under
accession number GCA_000403725.

\section{Introduction}

Corynebacterium ihumii strain GD7T sp. nov. (= CSUR P902, = DSM 45751) is the type strain of _Corynebacterium ihumii strain GD7T sp. nov. This bacterium is a Gram-positive, facultativly anaerobic, non spore-forming, non-motile bacillus that was isolated from the stool of a 62 year-old French male who was admitted to the intensive care unit in the Timone Hospital, Marseille, France, for respiratory distress. This strain was isolated as a part of "culturomics" project whose scope is to cultivate all species within human feces $[1,2]$.

The current classification of prokaryotes is based on a combination of phenotypic and genotypic characteristics $[3,4]$ that include $16 \mathrm{~S}$ rRNA gene phylogeny and nucleotide sequence similarity, $\mathrm{G}+$ $\mathrm{C}$ content and DNA-DNA hybridization (DDH). Despite being considered as a "gold standard" these genotypic tools exhibit several drawbacks that are overcome by newer sequencing methods $[5,6]$. Because of the rapidly declining cost of sequencing, the number of sequenced bacterial genomes rapidly increased (almost 7,000 to date [7]). Hence, we recently proposed to incorporate ge- nomic information among criteria used for the description of new bacterial species [8-29].

Corynebacteria are Gram-positive bacteria that belong to the phylum Actinobacteria and have a high $\mathrm{G}+\mathrm{C}$ content. They are found in diverse ecological niches such as soil, clinical specimens, cheese smear, vegetables, sewage etc. The genus Corynebacterium was created by Lehmann and Neumann in 1896 [30] which currently comprises 112 distinct species and 11 subspecies [31]. Many Corynebacterium species are involved in human and animal diseases and include $C$. diphtheriae [32], C. jeikeium, C. urealyticum, C. striatum, C. pseudotuberculosis, and C. ulcerans [33]. Others have industrial applications for amino acid production like C. glutamicum [34].

Here, we present a summary classification and a set of features for_Corynebacterium ihumii strain GD7T sp. nov. (=CSUR P902, =DSM 45751) together with the description of the genome sequencing and annotation.

\section{Classification and Features}

A stool sample was collected from a 62 year-old male admitted to the intensive care unit of the 
Timone Hospital in Marseille, France. The patient gave a written informed consent for the study. The study was approved by the Ethics Committee of the Institut Fédératif de Recherche IFR48, Faculty of Medicine, Marseille, France, under agreement number 09-022. The fecal specimen was pre- served at $-80^{\circ} \mathrm{C}$ after collection. Strain GD7T (Table 1) was isolated in January 2012 by cultivation on PVX agar (BioMerieux, Marcy l'Etoile, France) in aerobic condition with $5 \% \mathrm{CO}_{2}$ at $37^{\circ} \mathrm{C}$, after 21 days of incubation.

Table 1. Classification and general features

\begin{tabular}{|c|c|c|c|}
\hline MIGS ID & Property & Term & Evidence code $^{\mathrm{a}}$ \\
\hline & \multirow{8}{*}{ Current classification } & Domain Bacteria & TAS [36] \\
\hline & & Phylum Actinobacteria & TAS [37] \\
\hline & & Class Actinobacteria & TAS [38] \\
\hline & & Order Actinomycetales & TAS [38-41] \\
\hline & & Family Corynebacteriaceae & TAS $[38-40,42]$ \\
\hline & & Genus Corynebacterium & TAS $[39,43,44]$ \\
\hline & & Species_Corynebacterium ihumii & IDA \\
\hline & & Type strain GD7 & IDA \\
\hline & Gram stain & positive & IDA \\
\hline & Cell shape & rod & IDA \\
\hline & Motility & non motile & IDA \\
\hline & Sporulation & non endospore forming & IDA \\
\hline & Temperature range & mesophilic & IDA \\
\hline & Optimum temperature & $37^{\circ} \mathrm{C}$ & IDA \\
\hline MIGS-6.3 & Salinity & unknown & IDA \\
\hline \multirow[t]{3}{*}{ MIGS-22 } & Oxygen requirement & facultative anaerobic & IDA \\
\hline & Carbon source & unknown & NAS \\
\hline & Energy source & unknown & NAS \\
\hline MIGS-6 & Habitat & human gut & IDA \\
\hline MIGS-15 & Biotic relationship & free living & IDA \\
\hline MIGS-14 & $\begin{array}{l}\text { Pathogenicity } \\
\text { Biosafety level } \\
\text { Isolation }\end{array}$ & $\begin{array}{l}\text { unknown } \\
2 \\
\text { human feces }\end{array}$ & IDA \\
\hline MIGS-4 & Geographic location & France & IDA \\
\hline MIGS-5 & Sample collection time & January 2012 & IDA \\
\hline MIGS-4.1 & Latitude & 43.296482 & IDA \\
\hline MIGS-4.1 & Longitude & 5.36978 & IDA \\
\hline MIGS-4.3 & Depth & Surface & IDA \\
\hline MIGS-4.4 & Altitude & $0 \mathrm{~m}$ above sea level & IDA \\
\hline
\end{tabular}

aEvidence codes - IDA: Inferred from Direct Assay; TAS: Traceable Author Statement (i.e., a direct report exists in the literature); NAS: Non-traceable Author Statement (i.e., not directly observed for the living, isolated sample, but based on a generally accepted property for the species, or anecdotal evidence). These evidence codes are from the Gene Ontology project [45]. If the evidence is IDA, then the property was observed for a live isolate by one of the authors or an expert mentioned in the acknowledgements.

To understand the phylogenetic relationships of $C$. ihumii GD7T, we constructed a $16 \mathrm{~S}$ rRNA-based neighbor joining tree with 90 Corynebacterium species (Figure 1). The 16S rRNA sequence similarity among Corynebacterium species ranged from 82.9 to $99.60 \%$. Strain GD7T exhibited a highest $16 \mathrm{~S}$ rRNA sequence similarity of $99.1 \%$ with $C$. pilbarense. This value, although higher than the $98.7 \%$ 16S rRNA gene sequence threshold recommended by Stackebrandt and Ebers to delineate a new species without carrying out DNADNA hybridization [4], is in the range of values observed within the genus Corynebacterium. 


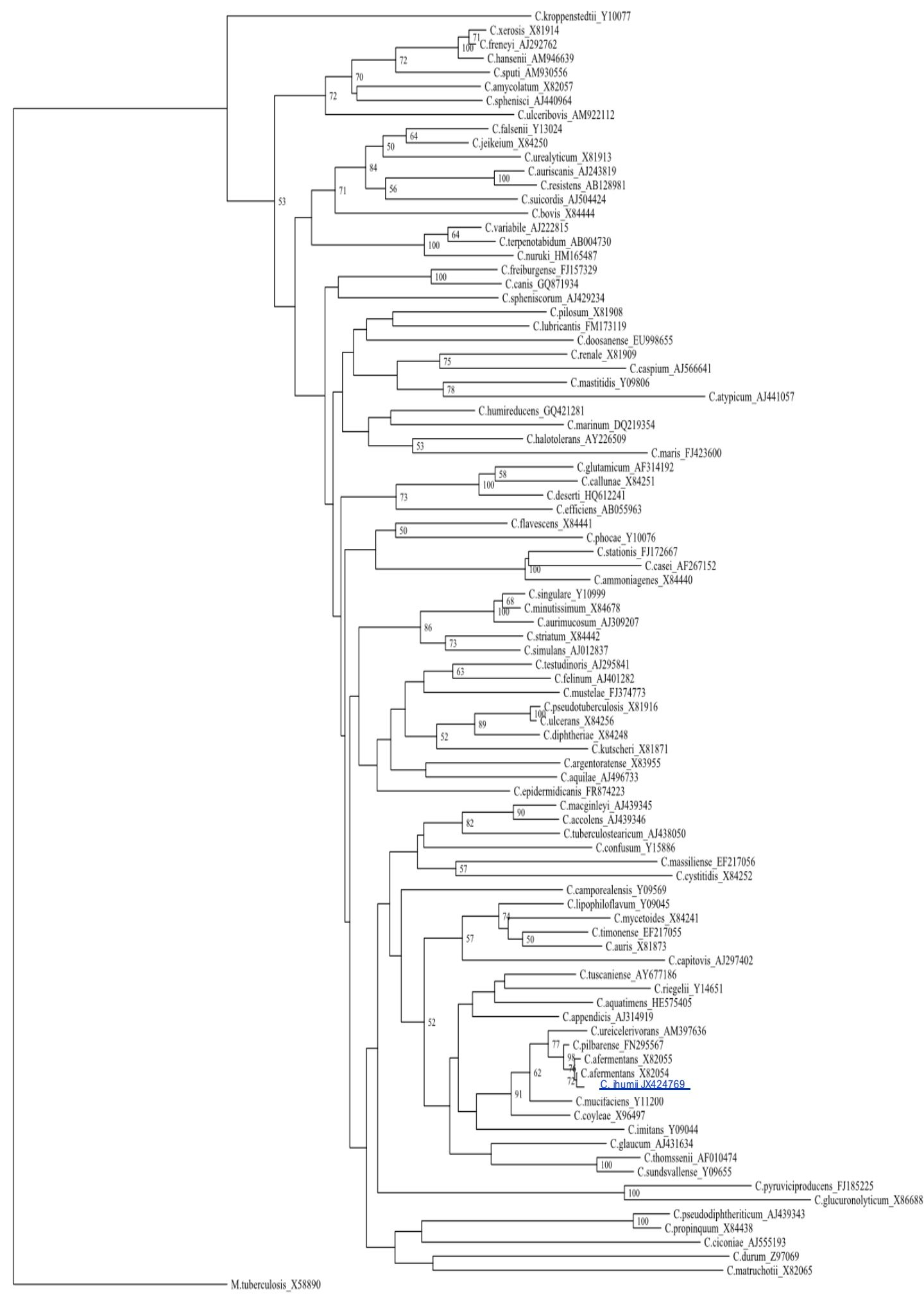

Figure 1. Phylogenetic tree highlighting the position of _Corynebacterium ihumii strain GD7 ${ }^{\top}$ relative to other type strains within the Corynebacterium genus. GenBank accession numbers are indicated for each strain. Sequences were aligned using CLUSTALW, and phylogenetic inferences obtained using the neighbor-joining method within the MEGA software. Numbers at the nodes are percentages of bootstrap values obtained by repeating the analysis 1,000 times to generate a majority consensus tree. Mycobacterium tuberculosis was used as an outgroup. The scale bar represents a $2 \%$ nucleotide sequence divergence. 


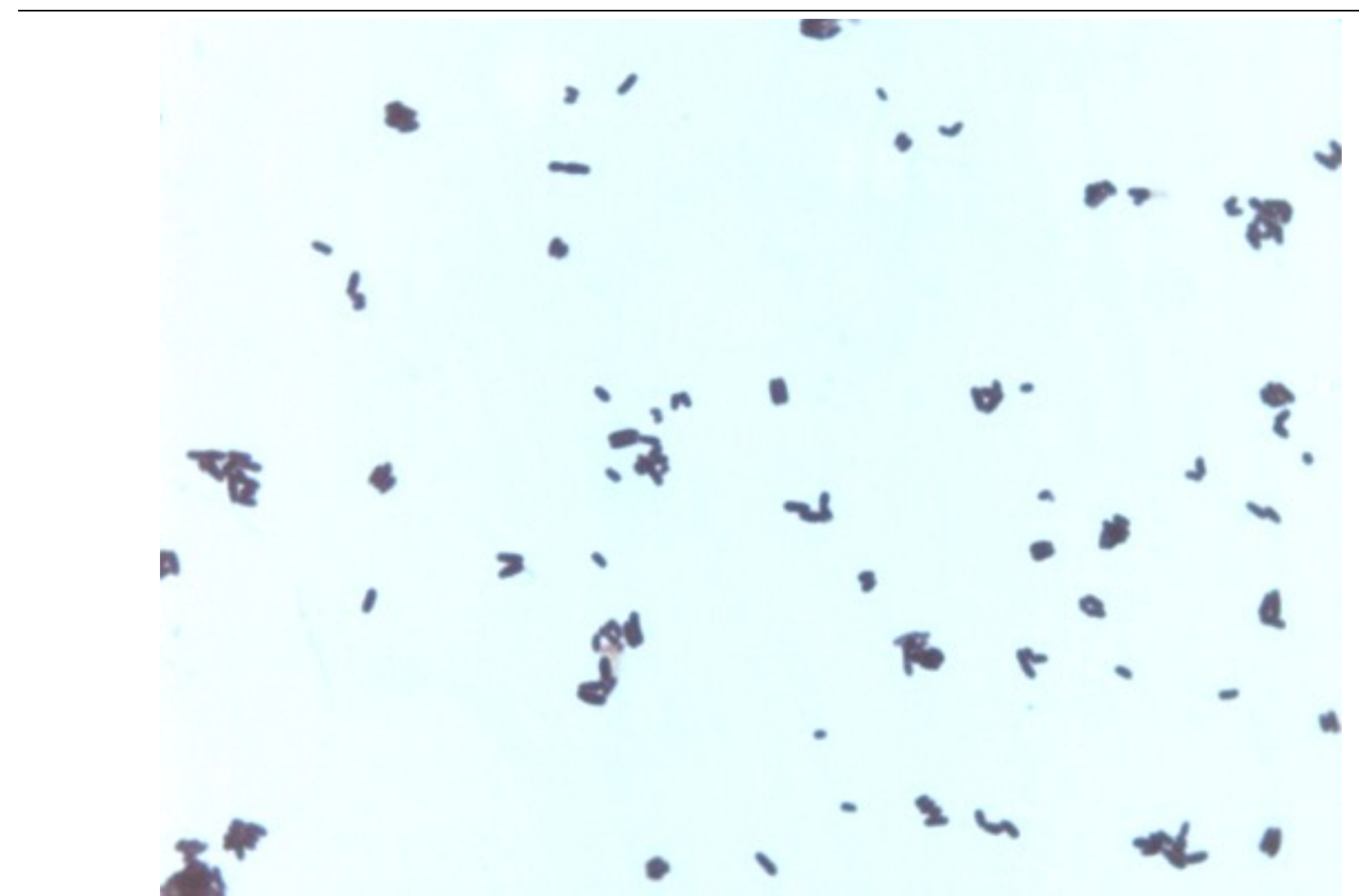

Figure 2. Gram stain of C. ihumii strain GD7 ${ }^{\top}$

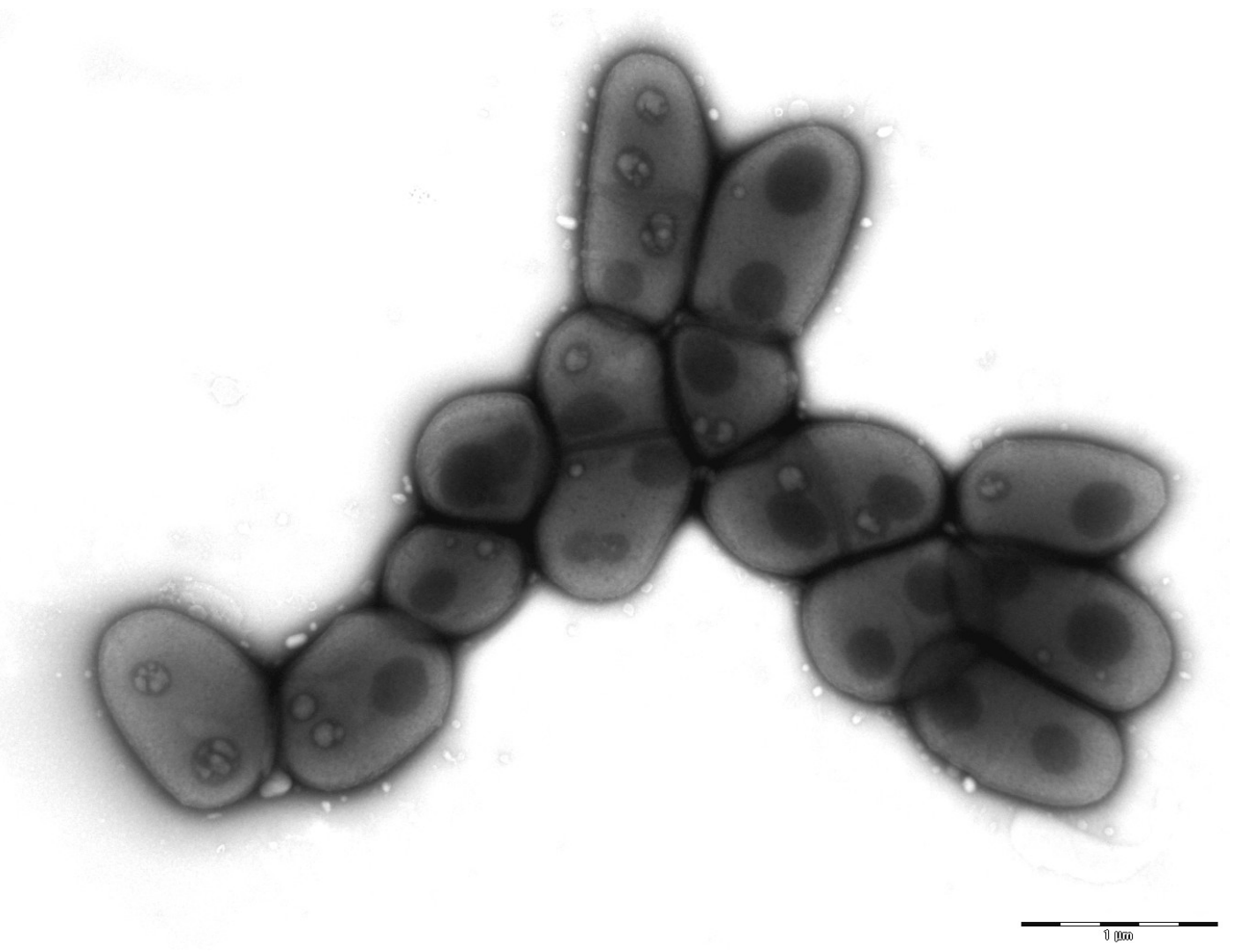

Figure 3. Transmission electron microscopy of C. ihumii strain $\mathrm{GD}^{\top}$, using a Morgani $268 \mathrm{D}$ (Philips) at an operating voltage of $60 \mathrm{kV}$. The scale bar represents $1 \mu \mathrm{m}$. 
Various growth temperatures $(25,30,37,45$ and $56^{\circ} \mathrm{C}$ ) were tested. Growth occurred between 30 and $45^{\circ} \mathrm{C}$ on blood-enriched Columbia agar (BioMérieux), with the optimal growth being obtained at $37^{\circ} \mathrm{C}$. Growth of the strain was tested under anaerobic and microaerophilic conditions using the GENbag Anaer and GENbag microaer systems, respectively (BioMérieux), and under aerobic conditions, with or without $5 \% \mathrm{CO}_{2}$. Optimal growth was achieved aerobically, but cell growth was also observed under microaerophilic and anaerobic conditions. The motility test was negative and the cells were nonsporulating. Colonies were white and granular with a diameter of $0.5 \mathrm{~mm}$ on blood-enriched Columbia agar (BioMérieux). Gram staining showed short Grampositive rods (Figure 2). By electron microscopy, cells grown on agar had a mean length and diameter of $1.26 \mu \mathrm{m}$ (range $1.1-1.4$ ) and $0.7 \mu \mathrm{m}$ (range 0.6-0.85), respectively (Figure 3)Strain GD7T was catalase positive and oxidase negative. Using the API ZYM system (BioMérieux), positive reactions were observed for alkaline phosphatase, leucine arylamidase, valine arylamidase, cystine arylamidase, acid phosphatase and naphthol-ASBI-phosphohydrolase. Negative reactions were observed for esterase (C4), esterase lipase (C8), lipase (C14), trypsin, $\alpha$-chemotrypsin, $\alpha$ galactosidase, $\beta$-galactosidase, $\beta$-glucuronidase, $\alpha$ glucosidase, $N$ actetyl- $\beta$-glucosaminidase, $\alpha$ mannosidase and $\alpha$-fucosidase. Using the API CORYNE system (BioMérieux), positive reactions were observed for pyrazinamidase, alkaline phosphatase, and glucose and ribose fermentation. Negative reactions were observed for reduction of nitrates, pyrolidonyl arylamidase; $\beta$ glucuronidase, $\beta$-galactosidase, $\alpha$-glucosidase $\mathrm{N}$ acetyl- $\beta$-glucosaminidase, $\beta$-glucosidase, urease, gelatin hydrolysis, fermentation of xylose, mannitol, maltose, lactose, saccharose and glycogen. Using an API 50CH strip (BioMérieux), positive reactions were observed for fermentation of L-arabinose, D-ribose, D-xylose, methyl- $\beta \mathrm{D}$ xylopranoside, D-galactose, D-glucose, D-fructose, D-mannose, L-rhamnose, D-mannitol, methyl- $\alpha \mathrm{D}$ xylopranoside, methyl- $\alpha \mathrm{D}$-glucopranoside, $\mathrm{N}$ acetylglucosamine, amygdalin, arbutin, salicin, Dcellobiose, D-maltose, D-lactose, D-mellibiose, Dsaccharose, D-trehalose, inulin, D-raffinose, amidon, glycogen and D-lyxose. Negative reactions were observed for fermentation of glycerol, erythritol, D-arabinose, L-xylose, D-adonitol, Lsorbose, dulcitol, inositol, D-sorbitol, esculin ferric citrate, D-melezitose, D- xylitol, gentiobiose, Dturanose, D-tagatose, D-fucose, L-fucose, Darabitol, L-arabitol, potassium gluconate, and potassium 2-ketogluconate. Table 2 summarizes the differential phenotypic characteristics of $C$. ihumii, C. pilbarense, C. coylae, C. glaucum, and C. mucifaciens. C. ihumii strain GD7T was susceptible to amoxicillin, amoxicillin-clavulanic acid, ceftriaxone, imipenem, doxycycline, vancomycin, erythromycin, rifampicin, trimethoprim/sulfamethoxazole and ciprofloxacine whereas it was resistant to metronidazole.

Matrix-assisted laser-desorption/ionization timeof-flight (MALDI-TOF) MS protein analysis was peformed as previously described [46] using a Microflex spectrometer (Bruker Daltonics, Leipzig, Germany). The spectra from twelve isolated distinct GD7T colonies were imported into the MALDI BioTyper software (version 2.0, Bruker) and analyzed by standard pattern matching (with default parameter settings) against the main spectra of 4,706 bacteria, including spectra from validated Corynebacterium species, that were part of the reference data contained in the BioTyper database. The presumptive identification and discrimination of the tested species from those in the database was interpreted as follows: a score $>2$ with a validly published species enabled the identification at the species level; a score $>1.7$ but $<2$ enabled the identification at the genus level; and a score $<1.7$ did not enable any identification. For strain GD7T, no significant score was obtained, suggesting that GD7 isolate was not a member of any known species or genus (Figures 4 and 5).

\section{Genome sequencing information}

\section{Genome project history}

As part of a 'culturomics' study of the human digestive flora, this organism was isolated and selected for sequencing on the basis of its phenotypic differences, phylogenetic position and 16S rRNA and $r p o B$ sequence similarity to other members of the genus Corynebacterium $[1,2]$. It is the first sequenced genome of $C$. ihumii sp. nov. The GenBank Bioproject number is PRJEB646 and consists of 41 large contigs in 5 scaffolds. Table 3 shows the project information and its association with MIGS version 2.0 compliance [47]. 
Table 2. Differential characteristics of C. ihumii, C. pilbarense, C. coylae, C. glaucum and C. mucifaciens.

\begin{tabular}{|c|c|c|c|c|c|}
\hline Properties & C. ihumii & C. pilbarense & C. coylae & C. glaucum & C. mucifaciens \\
\hline Colony size $(\mathrm{mm})$ & 0.5 & $0.5-2.0$ & 1.0 & na & $1.0-1.5$ \\
\hline Oxygen requirement & $\begin{array}{l}\text { facultative } \\
\text { anaerobic }\end{array}$ & $\begin{array}{l}\text { facultative } \\
\text { anaerobic }\end{array}$ & $\begin{array}{l}\text { facultative } \\
\text { anaerobic }\end{array}$ & $\begin{array}{l}\text { facultative } \\
\text { anaerobic }\end{array}$ & facultative anaerobi \\
\hline Gram stain & + & + & + & + & + \\
\hline Motility & - & - & - & - & - \\
\hline Endospore formation & - & - & - & - & - \\
\hline \multicolumn{6}{|l|}{ Production of } \\
\hline Alkaline phosphatase & + & + & + & + & + \\
\hline Acid phosphatase & + & + & + & - & + \\
\hline Catalase & + & + & + & + & + \\
\hline Oxidase & - & - & - & - & - \\
\hline Nitrate reductase & - & - & - & - & - \\
\hline Urease & - & - & - & - & - \\
\hline$\alpha$-galactosidase & - & - & - & - & - \\
\hline$\beta$-galactosidase & - & - & - & - & - \\
\hline$\beta$-glucuronidase & - & - & - & - & - \\
\hline$\alpha$-glucosidase & - & - & - & - & - \\
\hline$\beta$-glucosidase & - & - & - & - & - \\
\hline Esterase & - & - & + & - & + \\
\hline Esterase lipase & - & - & + & + & + \\
\hline $\begin{array}{l}\text { naphthol-AS-BI- } \\
\text { phosphohydrolase }\end{array}$ & + & + & na & + & na \\
\hline $\mathrm{N}$-acetyl- $\beta$-glucosaminidase & - & - & - & - & - \\
\hline Pyrazinamidase & + & + & + & + & + \\
\hline$\alpha$-mannosidase & - & - & - & - & - \\
\hline$\alpha$-fucosidase & - & - & - & - & - \\
\hline Leucine arylamidase & + & + & + & + & na \\
\hline Valine arylamidase & + & - & - & - & - \\
\hline Cystine arylamidase & - & - & + & - & + \\
\hline$\alpha$-chemotrypsin & - & - & - & - & - \\
\hline Trypsin & - & - & - & - & - \\
\hline \multicolumn{6}{|l|}{ Utilization of } \\
\hline 5-keto-gluconate & - & na & + & na & - \\
\hline D-xylose & + & - & - & - & - \\
\hline D-fructose & + & na & + & na & + \\
\hline D-glucose & + & + & + & + & + \\
\hline D-mannose & + & na & + & na & + \\
\hline Habitat & Human gut & $\begin{array}{l}\text { Human joint } \\
\text { fluid }\end{array}$ & $\begin{array}{l}\text { Human } \\
\text { blood }\end{array}$ & $\begin{array}{l}\text { Cosmetic } \\
\text { dye }\end{array}$ & Human blood \\
\hline
\end{tabular}




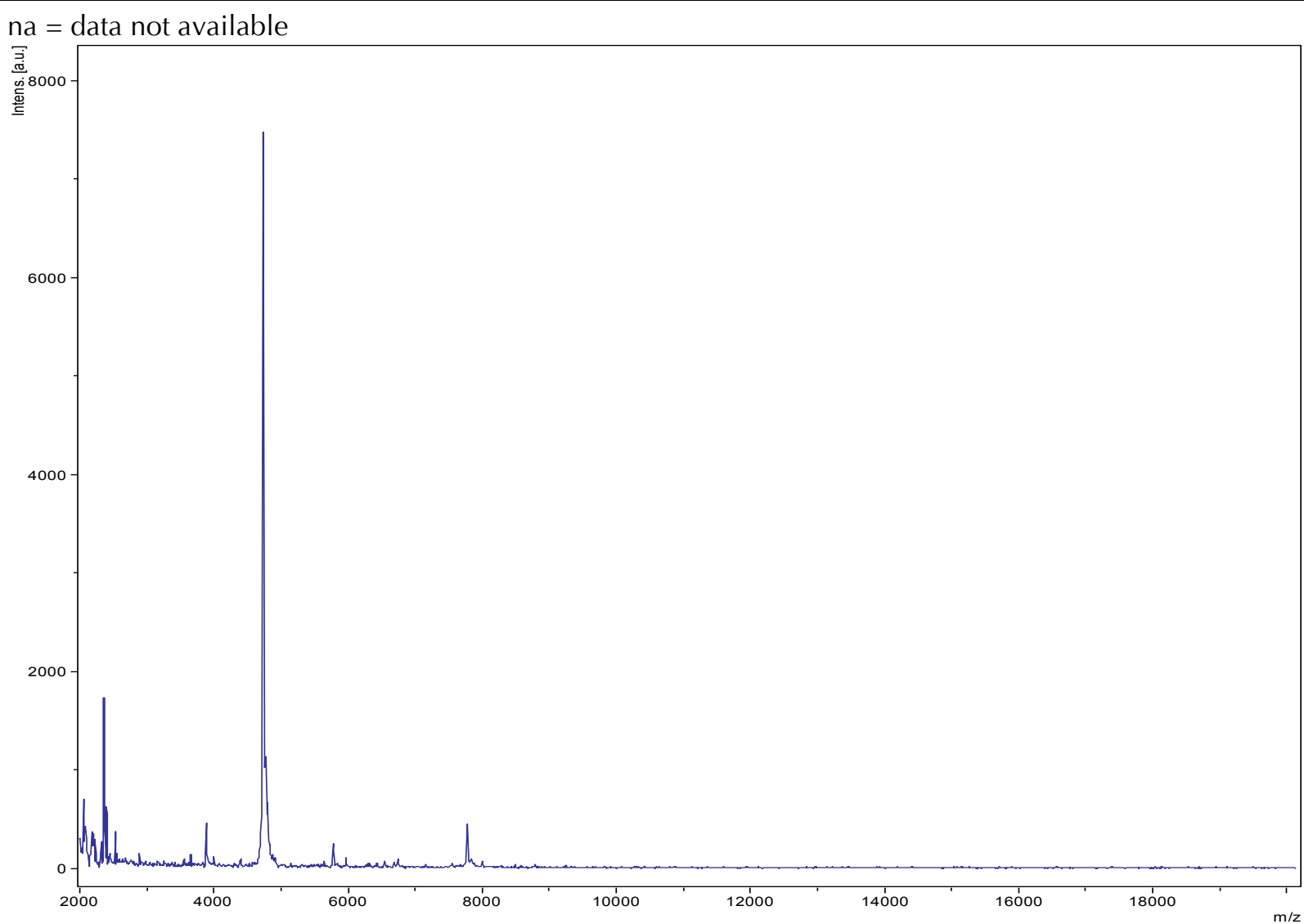

Figure 4. Reference mass spectrum from C. ihumii strain $G D 7^{\top}$. Spectra from 12 individual colonies were compared and a reference spectrum was generated.

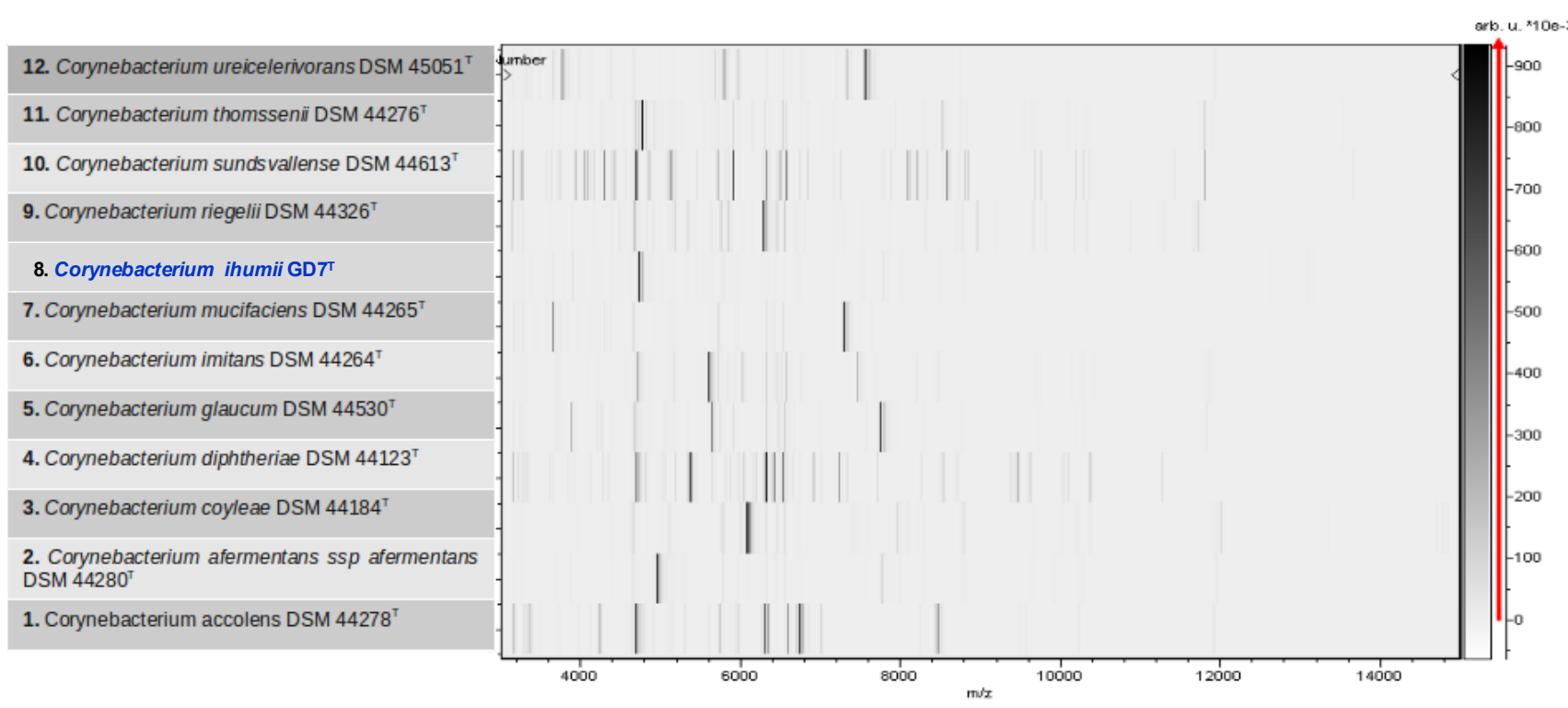

Figure 5: Gel view comparing C. ihumii sp. nov. strain GD7 ${ }^{\top}(=$ CSUR P902 = DSM 45751) to other members of the Corynebacterium genus. The gel view displays the raw spectra of all loaded spectrum files arranged in a pseudo-gel like look. The $\mathrm{x}$-axis records the $\mathrm{m} / \mathrm{z}$ value. The left $\mathrm{y}$-axis displays the running spectrum number originating from subsequent spectra loading. The peak intensity is expressed by a Gray scale scheme code. The color bar and the right $y$-axis indicate the relation between the color a peak is displayed with and the peak intensity in arbitrary units. 
Table 2. Project information

\begin{tabular}{lll}
\hline MIGS ID & Property & Term \\
\hline MIGS-31 & Finishing quality & High-quality draft \\
MIGS-28 & Libraries used & One 454 paired end 3-kb library \\
MIGS-29 & Sequencing platforms & 454 GS FLX Titanium \\
MIGS-31.2 & Fold coverage & $30 \times$ \\
MIGS-30 & Assemblers & Newbler version 2.5.3 \\
MIGS-32 & Gene calling method & Prodigal \\
& BioProject ID & PRJEB646 \\
& Genbank Assembly ID & GCA_000403725.1 \\
& Genbank Accession & CAVS000000000 \\
& number & \\
& Genbank Date of Release & 2013/05/29 \\
MIGS-13 & Project relevance & Study of the human gut microbiome \\
\hline
\end{tabular}

\section{Growth conditions and DNA isolation}

C. ihumii sp. nov. strain GD7T strain was cultivated in Columbia broth (BioMérieux) at $37^{\circ} \mathrm{C}$. Chromosomal DNA was extracted from $50 \mathrm{~mL}$ of culture, following centrifugation at $4^{\circ} \mathrm{C}$ at $2000 \mathrm{xg}$ for 20 min. Cell pellets were resuspended in $1 \mathrm{~mL}$ Tris/EDTA/NaCl [10mM Tris/HCl (pH7.0), $10 \mathrm{mM}$ EDTA (pH8.0), and $300 \mathrm{mM} \mathrm{NaCl}$ and recentrifuged under the same conditions. The pellets were then re-suspended in $200 \mu \mathrm{L}$ TE buffer and proteinase $\mathrm{K}$ and kept overnight at $37^{\circ} \mathrm{C}$ for cell lysis. DNA purification with phenol/chloroform/isoamylalcohol (25:24:1) was followed by an overnight precipitation with ethanol at $-20^{\circ} \mathrm{C}$. Then, the DNA was resuspended in 200 $\mu \mathrm{L}$ TE buffer. DNA concentration was $18.3 \mathrm{ng} / \mu \mathrm{l}$ as measured using the Genios Tecan fluorometer and the Quant-it Picogreen kit (Invitrogen).

\section{Genome sequencing and assembly}

The 454 GS-FLX Titanium paired-end protocol (Roche, Meylan, France) was used for the library construction of $C$. ihumii strain GD7T which was then pyrosequenced. Briefly, $3.7 \mu \mathrm{g}$ of purified chromosomal DNA was mechanically fragmented on the Covaris device (KBioScience-LGC Genomics, Middlesex, UK) through miniTUBE-Red with an enrichment size at $5 \mathrm{~kb}$. The DNA fragmentation was visualized through the Agilent 2100 BioAnalyzer on a DNA labchip 7500 with an optimal size of $2.5 \mathrm{~kb}$. Circularization and nebulization were performed on 100ng of the fragmented DNA and generated an optimal pattern of $443 \mathrm{bp}$. This was followed by 17 PCR amplification cycles followed by double size selection. The single stranded paired-end library was then quantified using
Quant-it Ribogreen kit (Invitrogen) on the Genios_Tecan fluorometer at $207 \mathrm{pg} / \mu \mathrm{L}$. The library concentration equivalence was calculated as $8.57 \mathrm{E}+08$ molecules $/ \mu \mathrm{L}$. The library was stored at $-20^{\circ} \mathrm{C}$ until further use. The shotgun library was clonally amplified with $0.5 \mathrm{cpb}$ and $1 \mathrm{cpb}$ in 2 emPCR reactions for each condition, using the GS Titanium SV emPCR Kit (Lib-L) v2 (Roche).The yield of the shotgun emPCR reactions was 5.27 and $7.56 \%$ respectively for the two kinds of paired-end emPCR reactions according to the quality expected (range of 5 to 20\%) from the Roche procedure. The library was loaded on the $1 / 4$ region of a GS Titanium PicoTiterPlate (PTP Kit 70x75, Roche) and pyrosequenced with the GS Titanium Sequencing Kit XLR70 and the GS FLX Titanium sequencer (Roche). The run was performed overnight and analyzed on the cluster through the gsRunBrowser and Newbler assembler (Roche). A total of 186,723 passed filter wells were obtained and generated $69.4 \mathrm{Mb}$ with a length average of $371 \mathrm{bp}$. The passed filter sequences were assembled using Newbler with $90 \%$ identity and $40 \mathrm{bp}$ as overlap. The assembly lead to 5 scaffolds and 41 large contigs (>1500bp) and generated a genome size of 2,232,265 bp which corresponds to a coverage of $30.84 \times$ genome equivalent.

\section{Genome annotation}

Open Reading Frames (ORFs) prediction was performed using Prodigal [48] with default parameters. The predicted ORFs were excluded if they spanned a sequencing gap region. Functional assessment of protein sequences was carried out by comparing them with sequences in the GenBank 
[49] and Clusters of Orthologus Groups (COG) databases using BLASTP. tRNAs, rRNAs, signal peptides and transmembrane helices were identified using tRNAscan-SE 1.21 [50], RNAmmer [51], SignalP [52] and TMHMM [53], respectively. ORFans were identified if their BLASTP $E$ - value was lower than $1 \mathrm{e}^{-3}$ for alignment lengths greater than 80 amino acids. If alignment lengths were smaller than 80 amino acids, we used an $E$-value of $1 \mathrm{e}^{-5}$ [54]. PHAST was used to identify, annotate and graphically display prophage sequences within bacterial genomes or plasmids [55]. Artemis [56] was used for data management whereas DNA Plotter [57] was used for visualization of genomic features. In-house perl and bash scripts were used to automate these routine tasks.

To estimate the mean level of nucleotide sequence similarity at the genome level between $C$. ihumii and another 42 members of the genus Corynebacterium, we used the Average Genomic Identity of Orthologous gene Sequences (AGIOS) home-made pipeline. Briefly, this pipeline combines the Proteinortho software (with the following parameters: e-value $1 \mathrm{e}^{-5}, 30 \%$ of identity, $50 \%$ coverage and algebraic connectivity of 50\%) [58] for detecting orthologous proteins between genomes compared pairwise, then retrieves the corresponding genes and determines the mean percentage of nucleotide sequence identity among orthologous ORFs using the Needleman-Wunsch global alignment algorithm.

\section{Genome properties}

The genome of $C$. ihumii sp. nov. strain GD7T is 2,232,265 bp long (1 chromosome in 5 scaffolds, no plasmid) with a $65.1 \%$ GC content (Table 4, Figure 6). Of the 2,182 predicted genes, 2,125 were protein-coding genes and 57 were RNAs (53 tRNA and 4 rRNA genes). A total of 1,562 genes (71.58\%) were assigned a putative function. Four hundred and twenty-two genes (19.8\%) were annotated as hypothetical proteins, and 126 genes ORFans (5.9\%). The distribution of genes into COGs functional categories is presented in Table 5. The properties and statistics of the genome are summarized in Tables 4 and 5. A quick search with PHAST revealed that $C$. ihumii harbors an incomplete bacteriophage.

Table 4. Nucleotide content and gene count levels of the genome

\begin{tabular}{lrr}
\hline Attribute & Value & \% of total \\
\hline Genome size (bp) & $2,232,265$ & \\
DNA Coding region (bp) & $2,041,113$ & 91.43 \\
DNA G+C content (bp) & $1,453,204$ & 65.1 \\
Number of replicons & 1 & \\
Extrachromosomal elements & 0 & 100 \\
Total genes & 2,182 & 2.61 \\
RNA genes & 57 & \\
rRNA operons & 1 & 97.38 \\
Predicted tRNA pseudogenes & 2,125 & 71.58 \\
Protein-coding genes & 1,562 & 78.04 \\
Genes with function prediction & 1,703 & 8.66 \\
Genes assigned to COGs & 189 & 25.34 \\
Genes with peptide signals & 553 & \\
Genes with transmembrane helices & 1 & \\
CRISPR repeats & &
\end{tabular}

${ }^{a}$ The total is based on either the size of the genome in base pairs or the total number of protein coding genes in the annotated genome 
Table 4. Number of genes associated with the 25 general COG functional categories

\begin{tabular}{|c|c|c|c|}
\hline Code & Value & $\%$ age $^{a}$ & Description \\
\hline J & 142 & 6.68 & Translation \\
\hline A & 1 & 0.05 & RNA processing and modification \\
\hline K & 131 & 6.16 & Transcription \\
\hline $\mathrm{L}$ & 114 & 5.36 & Replication, recombination and repair \\
\hline B & 0 & 0.00 & Chromatin structure and dynamics \\
\hline $\mathrm{D}$ & 19 & 0.89 & Cell cycle control, mitosis and meiosis \\
\hline Y & 0 & 0.00 & Nuclear structure \\
\hline V & 31 & 1.46 & Defense mechanisms \\
\hline $\mathrm{T}$ & 60 & 2.82 & Signal transduction mechanisms \\
\hline M & 95 & 4.47 & Cell wall/membrane biogenesis \\
\hline N & 1 & 0.05 & Cell motility \\
\hline Z & 0 & 0.00 & Cytoskeleton \\
\hline W & 0 & 0.00 & Extracellular structures \\
\hline$U$ & 22 & 1.04 & Intracellular trafficking and secretion \\
\hline $\mathrm{O}$ & 62 & 2.92 & Posttranslational modification, protein turnover, chaperones \\
\hline $\mathrm{C}$ & 83 & 3.91 & Energy production and conversion \\
\hline G & 100 & 4.71 & Carbohydrate transport and metabolism \\
\hline $\mathrm{E}$ & 158 & 7.44 & Amino acid transport and metabolism \\
\hline $\mathrm{F}$ & 63 & 2.96 & Nucleotide transport and metabolism \\
\hline $\mathrm{H}$ & 78 & 3.67 & Coenzyme transport and metabolism \\
\hline I & 46 & 2.16 & Lipid transport and metabolism \\
\hline $\mathrm{P}$ & 117 & 5.51 & Inorganic ion transport and metabolism \\
\hline Q & 35 & 1.64 & $\begin{array}{l}\text { Secondary metabolites biosynthesis, transport and catabo- } \\
\text { lism }\end{array}$ \\
\hline $\mathrm{R}$ & 204 & 9.60 & General function prediction only \\
\hline S & 141 & 6.63 & Function unknown \\
\hline- & 422 & 19.8 & Not in COGs \\
\hline
\end{tabular}

${ }^{a}$ The total is based on the total number of protein coding genes in the annotated genome.

\section{Comparative genomics}

Presently there are more than 75 genomic sequences (finished or draft) available for Corynebacterium species in GenBank. Here, we have compared $C$. ihumii sp. nov. strain GD7T with 41 finished or draft genome sequences from 25 Corynebacterium species. Table 6 shows a compar- ison of genome size, GC\%, coding-density, and numbers of proteins for the compared Corynebacterium genomes. C. ihumii had a smaller genome than all other compared genomes except that of $C$. urealyticum strain DSM 7111. AGIOS values identities ranged from 65.23 to $80.59 \%$ among Corynebacterium species, and from 97.97 


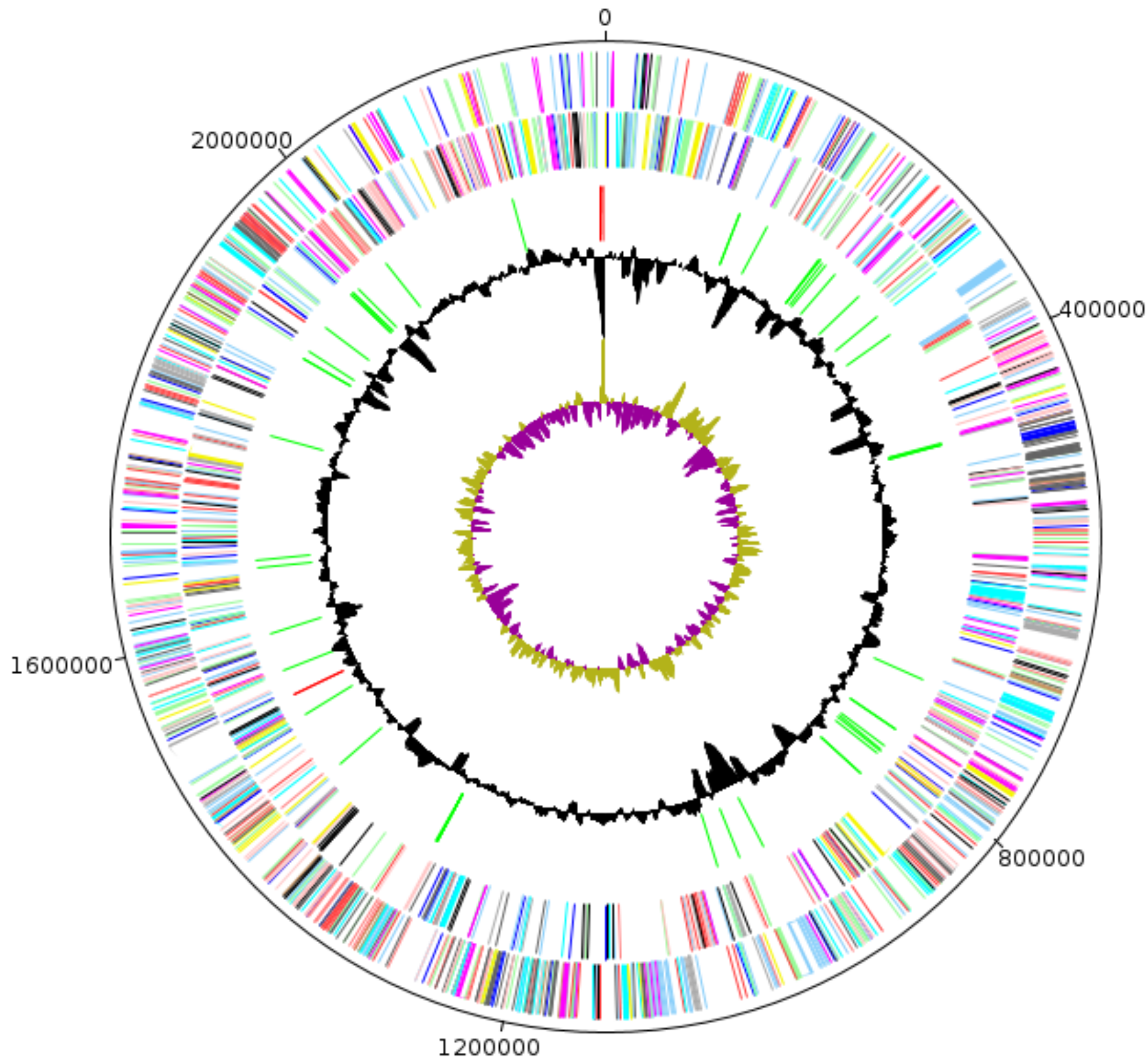

Figure 6. Graphical circular map of the chromosome. From the outside in, the outer two circles show open reading frames oriented in the forward and reverse directions (colored by COG categories), respectively. The third circle marks the rRNA gene operon (red) and tRNA genes (green). The fourth circle shows the $\mathrm{G}+\mathrm{C} \%$ content plot. The inner-most circle shows the GC skew, purple and olive indicating negative and positive values, respectively.

to $99.99 \%$ within Corynebacterium species (Supplementary Table). By comparison with other species, C. ihumii exhibited AGIOS values ranging from $67.15 \%$ with C. pseudotuberculosis to $76.30 \%$ with C. lipophiloflavum, thus confirming its new species status.

Figure 7 shows the comparison of gene distribution into COG categories of $C$. ihumii with $C$. glutamicum strain ATCC 13032, C. efficiens YS 314, C. jeikeium K411, C. aurimucosum ATCC 700975, C. kroppenstedtii DSM 44385, C. resistens DSM 45100, C. variabile DSM 44702, C. diphtheriae BH8, C. pseudotuberculosis 1002, C. ulcerans 0102, C. halotolerans YIM 70093 and C. callunae DSM 20147. The overall COG distribution is similar, except $C$. variabile for category $L$ genes. 


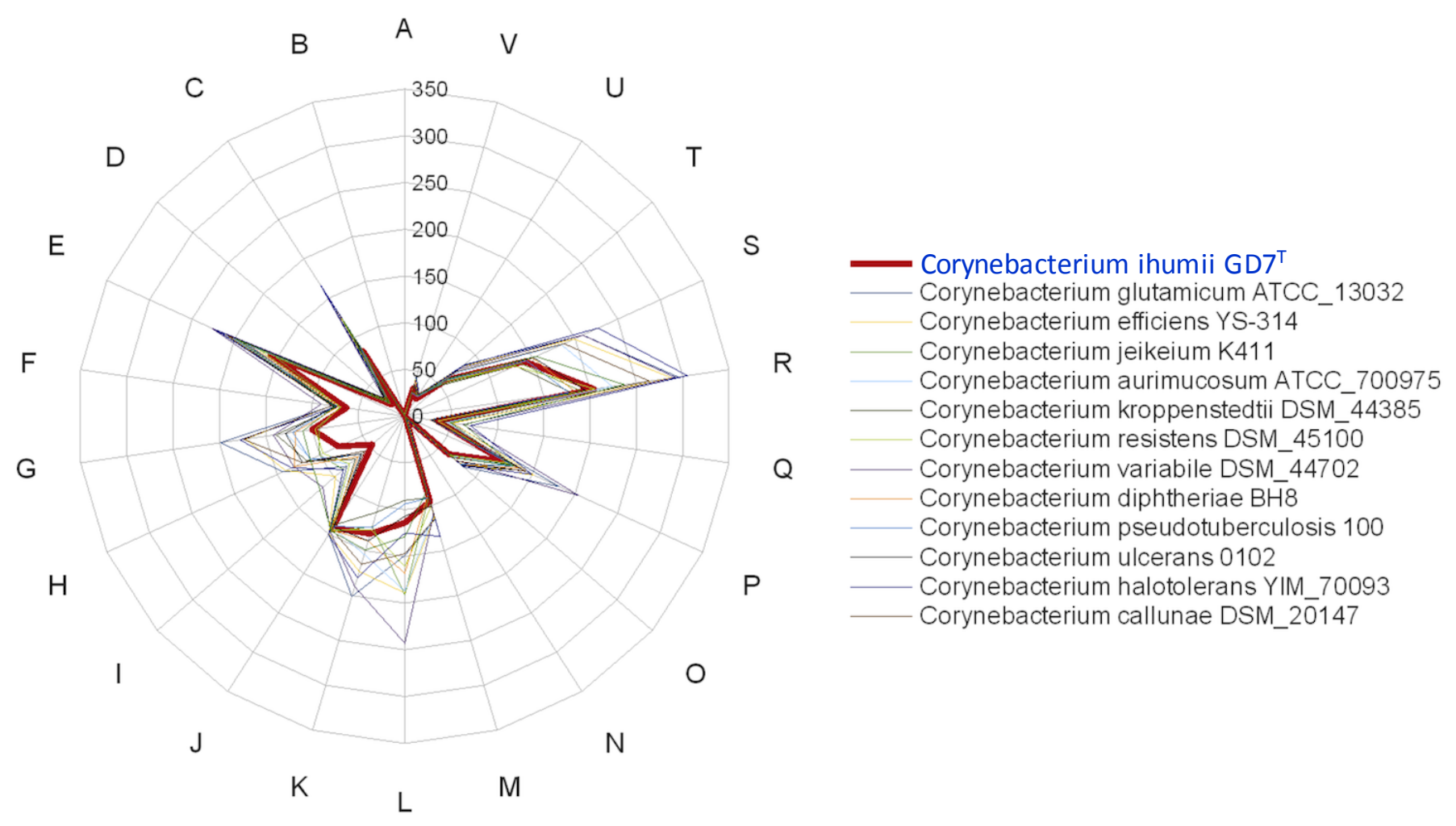

Figure 7. Distribution of functional classes of predicted genes of Corynebacterium ihumii strain GD7 ${ }^{\top}$ (colored in thick red line) along with other Corynebacterium genomes according to the clusters of orthologous groups of proteins.

\section{Conclusion}

On the basis of phenotypic, phylogenetic and genomic analyses, we formally propose the creation of _Corynebacterium ihumii sp. nov. which contains strain GD7T (= CSUR P902 = DSM 45751). This bacterium was isolated from the fecal flora of a 62 year-old male admitted in intensive care unit for respiratory distress.

\section{Description of Corynebacterium ihumii strain $\mathrm{GD7}^{\mathrm{T}}$ sp. nov.}

Colonies are white and granular with a $0.5 \mathrm{~mm}$ diameter on blood-enriched Columbia agar. Cells are rod-shaped with a mean length and diameter of $1.26 \mu \mathrm{m}$ (range $1.1-1.4$ ) and $0.7 \mu \mathrm{m}$ (range 0.6$0.85)$, respectively. Growth is observed between 30 and $45^{\circ} \mathrm{C}$, with optimal growth obtained at $37^{\circ} \mathrm{C}$ on blood-enriched Columbia agar. Optimal growth is achieved aerobically, but cell growth is also observed under microaerophilic and anaerobic conditions. Cells stain Gram-positive, are nonmotile and nonsporulating. Catalase is posi- tive, oxidase is negative. Using the API ZYM system, positive reactions are observed for alkaline phosphatase, leucine arylamidase, valine arylamidase, cystin arylamidase, acid phosphatase and naphthol-AS-BI-phosphohydrolase. Negative reactions are observed for esterase (C4), esterase lipase (C8), lipase (C14), trypsin, $\alpha$-chemotrypsin, $\alpha$-galactosidase, $\beta$-galactosidase, $\beta$-glucuronidase, $\alpha$-glucosidase, $N$ actetyl- $\beta$-glucosaminidase, $\alpha$ mannosidase and $\alpha$-fucosidase. Using the API CORYNE system, positive reactions are observed for pyrazinamidase, alkaline phosphatase, and glucose and ribose fermentation. Negative reac tions are observed for reduction of nitrates, pyrolidonyl arylamidase; $\beta$-glucuronidase, $\beta$ galactosidase, $\alpha$-glucosidase $\quad \mathrm{N}$-acetyl- $\beta$ glucosaminidase, $\beta$-glucosidase, urease, gelatin hydrolysis, fermentation of xylose, mannitol, maltose, lactose, saccharose and glycogen. Using the API 50CH system, positive reactions are observed for fermentation of L-arabinose, D-ribose, 
D-xylose, methyl- $\beta$ D xylopranoside, D-galactose,

D-glucose, D-fructose, D-mannose, L-rhamnose,

Table 6. Main characteristics of Corynebacterium genomes compared to that of C. ihumii strain GD7' .

\begin{tabular}{|c|c|c|c|c|c|c|}
\hline Species & Strain & NCIBI ID & $\begin{array}{l}\text { Coding } \\
\text { density }\end{array}$ & Length (bp) & GC\% & Proteins \\
\hline Corynebacterium ihumii & $\mathrm{GD7}^{\top}$ & & 90.65 & $2,232,265$ & 64.95 & 2,125 \\
\hline Corynebacterium accolens & ATCC 49726 & uid52361 & 86.51 & $2,465,976$ & 59.23 & 2,360 \\
\hline Corynebacterium ammoniagenes & DSM 20306 & uid48813 & 90.3 & $2,764,417$ & 55.56 & 2,654 \\
\hline Corynebacterium amycolatum & SK46 & uid55411 & 85.4 & $2,514,382$ & 58.58 & 2,103 \\
\hline Corynebacterium casei & & uid78139 & 85.95 & $3,113,786$ & 55.34 & 2,700 \\
\hline Corynebacterium aurimucosum & ATCC 700975 & uid59409 & 88.49 & $2,790,189$ & 60.63 & 2,531 \\
\hline Corynebacterium bovis & DSM 20582 & uid67345 & 85.72 & $2,527,982$ & 72.55 & 2,339 \\
\hline Corynebacterium diphtheriae & VA01 & uid84305 & 88.36 & $2,395,441$ & 53.44 & 2,191 \\
\hline Corynebacterium diphtheriae & $\mathrm{HC} 01$ & uid84297 & 88.03 & $2,427,149$ & 53.43 & 2,248 \\
\hline Corynebacterium diphtheriae & $\mathrm{HCO} 2$ & uid84317 & 87.7 & $2,468,612$ & 53.71 & 2,230 \\
\hline Corynebacterium diphtheriae & INCA 402 & uid83605 & 87.72 & $2,449,071$ & 53.65 & 2,214 \\
\hline Corynebacterium diphtheriae & NCTC 13129 & uid57691 & 87.96 & $2,488,635$ & 53.48 & 2,272 \\
\hline Corynebacterium diphtheriae & 241 & uid83607 & 87.87 & $2,426,551$ & 53.43 & 2,245 \\
\hline Corynebacterium durum & F0235 & uid183766 & 90.37 & $2,809,766$ & 56.84 & 2,823 \\
\hline Corynebacterium efficiens & YS 314 & uid62905 & 91.38 & $3,147,090$ & 63.14 & 2,938 \\
\hline Corynebacterium genitalium & ATCC 33030 & uid52785 & 90.81 & $2,349,953$ & 62.73 & 2,226 \\
\hline Corynebacterium glucuronolyticum & ATCC 51867 & uid55397 & 85.44 & $2,809,779$ & 59.09 & 2,645 \\
\hline Corynebacterium glutamicum & $\mathrm{R}$ & uid58897 & 86.83 & $3,314,179$ & 54.13 & 3,052 \\
\hline Corynebacterium glutamicum & ATCC 13032 & uid57905 & 86.41 & $3,309,401$ & 53.81 & 2,993 \\
\hline Corynebacterium glutamicum & ATCC 13032 & uid61611 & 87.53 & $3,282,708$ & 53.84 & 3,057 \\
\hline Corynebacterium jeikeium & K411 & uid58399 & 89.41 & $2,462,499$ & 61.4 & 2,104 \\
\hline Corynebacterium kroppenstedtii & DSM 44385 & uid59411 & 86.73 & $2,446,804$ & 57.46 & 2,018 \\
\hline Corynebacterium lipophiloflavum & DSM 44291 & uid55469 & 87.87 & $2,386,544$ & 64.26 & 2,371 \\
\hline Corynebacterium matruchotii & ATCC 14266 & uid51885 & 86.43 & $2,856,058$ & 57.09 & 2,619 \\
\hline Corynebacterium nuruki & S6 4 & uid77677 & 89.61 & $3,107,265$ & 69.49 & 2,797 \\
\hline Corynebacterium pseudogenitalium & ATCC 33035 & uid55395 & 89.9 & $2,601,506$ & 59.53 & 2,493 \\
\hline Corynebacterium pseudotuberculosis & FRC41 & uid50585 & 87.91 & $2,337,913$ & 52.19 & 2,110 \\
\hline Corynebacterium pseudotuberculosis & 1002 & uid159677 & 85.31 & $2,337,913$ & 52.19 & 2,090 \\
\hline Corynebacterium pseudotuberculosis & 267 & uid162175 & 86.54 & $2,337,628$ & 52.19 & 2,148 \\
\hline Corynebacterium pseudotuberculosis & $4202 \mathrm{~A}$ & uid159669 & 84.23 & $2,337,606$ & 52.19 & 2,051 \\
\hline Corynebacterium pseudotuberculosis & P54B96 & uid157909 & 84.93 & $2,337,657$ & 52.19 & 2,084 \\
\hline Corynebacterium resistens & DSM 45100 & uid50555 & 87.87 & $2,601,311$ & 57.09 & 2,171 \\
\hline Corynebacterium striatum & ATCC 6940 & uid55471 & 86.33 & $2,829,831$ & 59.05 & 2,677 \\
\hline Corynebacterium tuberculostearicum & SK141 & uid55413 & 89.57 & $2,372,621$ & 60.01 & 2,210 \\
\hline Corynebacterium ulcerans & 809 & uid159659 & 87.66 & $2,502,095$ & 53.3 & 2,180 \\
\hline Corynebacterium ulcerans & 102 & uid169879 & 87.66 & $2,579,188$ & 53.36 & 2,349 \\
\hline Corynebacterium ulcerans & BR AD22 & uid68291 & 87.72 & $2,606,374$ & 53.4 & 2,334 \\
\hline Corynebacterium urealyticum & DSM 7109 & uid61639 & 89.7 & $2,369,219$ & 64.19 & 2,022 \\
\hline
\end{tabular}

D-mannitol, methyl- $\alpha \mathrm{D}$-xylopranoside, methyl- $\alpha \mathrm{D}$ glucopranoside, N-acetylglucosamine, amygdalin, arbutin, salicin, D-cellobiose, D-maltose, D-lactose, D-mellibiose, D-saccharose, D-trehalose, inulin, D- raffinose, amidon, glycogen and D-lyxose. Negative reactions are observed for fermentation of glycerol, erythritol, D-arabinose, L-xylose, D-adonitol, Lsorbose, dulcitol, inositol, D-sorbitol, esculin ferric 
citrate, D-melezitose, D- xylitol, gentiobiose, Dturanose, D-tagatose, D-fucose, L-fucose, Darabitol, L-arabitol, potassium gluconate, and potassium 2-ketogluconate. Cells are susceptible to amoxicillin, amoxicillin-clavulanic acid, ceftriaxone, imipenem, doxycycline, vancomycin, erythromycin, rifampicin, trimethoprim/ sulfamethoxazole and ciprofloxacine but was resistant to metronidazole. The $\mathrm{G}+\mathrm{C}$ content of the genome is $65.1 \%$. The $16 \mathrm{~S}$ rRNA and genome sequences are deposited in GenBank under accession numbers JX424769 and CAVS000000000, respectively.

\section{Acknowledgments}

The authors thank the Xegen Company for automating the genomic annotation process. This study was funded by the Mediterranée-Infection foundation.

\section{References}

1. Lagier JC, Armougom F, Million M, Hugon P, Pagnier I, Robert C, Bittar F, Fournous G, Gimenez G, Maraninchi M, et al. Microbial culturomics: paradigm shift in the human gut microbiome study. Clin Microbiol Infect 2012; 18:1185-1193. PubMed

2. Dubourg G, Lagier JC, Armougom F, Robert C, Hamad I, Brouqui P, Raoult D. The gut microbiota of a patient with resistant tuberculosis is more comprehensively studied by culturomics than by metagenomics. Eur I Clin Microbiol Infect Dis 2013; 32:637-645. PubMed http://dx.doi.org/10.1007/s10096-012-1787-3

3. Tindall BJ, Rosselló-Móra R, Busse HJ, Ludwig W, Kämpfer P. Notes on the characterization of prokaryote strains for taxonomic purposes. Int I Syst Evol Microbiol 2010; 60:249-266. PubMed http://dx.doi.org/10.1099/ijs.0.016949-0

4. Stackebrandt E, Ebers J. Taxonomic parameters revisited: tarnished gold standards. Microbiol Today 2006; 33:152-155.

5. Wayne LG, Brenner DJ, Colwell RR. Report of the Ad Hoc Committee on Reconciliation of Approaches to Bacterial Systematics. Int J Syst Bacteriol 1987; 37:463-464. http://dx.doi.org/10.1099/00207713-37-4-463

6. Rossello-Mora R. DNA-DNA reassociation methods applied to microbial taxonomy and their critical evaluation. In: Molecular identification, systematics, and population structure of prokaryotes 2006:23-50.

7. Database GOLD. http://www.genomesonline.org/cgibin/GOLD/index.cgi
8. Kokcha S, Mishra AK, Lagier JC, Million M, Leroy Q, Raoult D, Fournier PE. Non contiguousfinished genome sequence and description of $\mathrm{Ba}$ cillus timonensis sp. nov. Stand Genomic Sci 2012; 6:346-355. PubMed http://dx.doi.org/10.4056/sigs.2776064

9. Lagier JC, El Karkouri K, Nguyen TT, Armougom F, Raoult D, Fournier PE. Non-contiguous finished genome sequence and description of Anaerococcus senegalensis sp. nov. Stand Genomic Sci 2012; 6:116-125. PubMed http://dx.doi.org/10.4056/sigs.2415480

10. Mishra AK, Gimenez G, Lagier JC, Robert C, Raoult D, Fournier PE. Genome sequence and description of Alistipes senegalensis sp. nov. Stand Genomic Sci 2012; 6:1-16. PubMed http://dx.doi.org/10.4056/sigs.2956294

11. Lagier JC, Armougom F, Mishra AK, Nguyen TT, Raoult D, Fournier PE. Non-contiguous finished genome sequence and description of Alistipes timonensis sp. nov. Stand Genomic Sci 2012; 6:315-324. PubMed http://dx.doi.org/10.4056/sigs.2685971

12. Mishra AK, Lagier JC, Robert C, Raoult D, Fournier PE. Non-contiguous finished genome sequence and description of Clostridium senegalense sp. nov. Stand Genomic Sci 2012; 6:386-395. PubMed

13. Mishra AK, Lagier JC, Robert C, Raoult D, Fournier PE. Non contiguous-finished genome sequence and description of Peptoniphilus timonensis sp. nov. Stand Genomic Sci 2012; 7:111. PubMed http://dx.doi.org/10.4056/sigs.2956294

14. Mishra AK, Lagier JC, Rivet R, Raoult D, Fournier $P E$. Non-contiguous finished genome sequence and description of Paenibacillus senegalensis sp. nov. Stand Genomic Sci 2012; 7:70-81. PubMed http://dx.doi.org/10.4056/sigs.3056450

15. Lagier JC, Gimenez G, Robert C, Raoult D, Fournier PE. Non-contiguous finished genome sequence and description of Herbaspirillum massiliense sp. nov. Stand Genomic Sci 2012; 7:200-209. PubMed

16. Roux V, El Karkouri K, Lagier JC, Robert C, Raoult D. Non-contiguous finished genome sequence and description of Kurthia massiliensis sp. nov. Stand Genomic Sci 2012; 7:221-232. PubMed http://dx.doi.org/10.4056/sigs.3206554

17. Kokcha S, Ramasamy D, Lagier JC, Robert C, Raoult D, Fournier PE. Non-contiguous finished genome sequence and description of Brevibacterium senegalense sp. nov. Stand Genomic Sci 2012; 7:233-245. PubMed http://dx.doi.org/10.4056/sigs.3256677 
18. Ramasamy D, Kokcha S, Lagier JC, Nguyen TT, Raoult D, Fournier PE. Genome sequence and description of Aeromicrobium massiliense sp. nov. Stand Genomic Sci 2012; 7:246-257. PubMed http://dx.doi.org/10.4056/sigs.3306717

19. Lagier JC, Ramasamy D, Rivet R, Raoult D, Fournier PE. Non contiguous-finished genome sequence and description of Cellulomonas massiliensis sp. nov. Stand Genomic Sci 2012; 7:258-270. PubMed http://dx.doi.org/10.4056/sigs.3316719

20. Lagier JC, Elkarkouri K, Rivet R, Couderc C, Raoult D, Fournier PE. Non contiguous-finished genome sequence and description of Senegalemassilia anaerobia gen. nov., sp. nov. Stand Genomic Sci 2013; 7:343-356. PubMed http://dx.doi.org/10.4056/sigs.3246665

21. Mishra AK, Hugon P, Lagier JC, Nguyen TT, Robert C, Couderc C, Raoult D, Fournier PE. Non contiguous-finished genome sequence and description of Peptoniphilus obesi sp. nov. Stand Genomic Sci 2013; 7:357-369. PubMed http://dx.doi.org/10.4056/sigs.32766871

22. Mishra AK, Lagier JC, Nguyen TT, Raoult D, Fournier PE. Non contiguous-finished genome sequence and description of Peptoniphilus senegalensis sp. nov. Stand Genomic Sci 2013; 7:370-381. PubMed http://dx.doi.org/10.4056/sigs.3366764

23. Lagier JC, El Karkouri K, Mishra AK, Robert C, Raoult D, Fournier PE. Non contiguous-finished genome sequence and description of Enterobacter massiliensis sp. nov. Stand Genomic Sci 2013; 7:399-412. PubMed http://dx.doi.org/10.4056/sigs.3396830

24. Hugon $P$, Ramasamy D, Lagier JC, Rivet R, Couderc C, Raoult D, Fournier PE. Non contiguous-finished genome sequence and description of Alistipes obesi sp. nov. Stand Genomic Sci 2013; 7:427-439. PubMed http://dx.doi.org/10.4056/sigs.3336746

25. Mishra AK, Hugon P, Robert C, Raoult D, Fournier PE. Non contiguous-finished genome sequence and description of Peptoniphilus grossensis sp. nov. Stand Genomic Sci 2012; 7:320-330. PubMed

26. Mishra AK, Hugon P, Lagier JC, Nguyen TT, Couderc C, Raoult D, Fournier PE. Non contiguous-finished genome sequence and description of Enorma massiliensis gen. nov., sp. nov., a new member of the Family Coriobacteriaceae. Stand Genomic Sci 2013; 8:290-305. PubMed http://dx.doi.org/10.4056/sigs.3426906

27. Ramasamy D, Lagier JC, Gorlas A, Raoult D, Fournier PE. Non contiguous-finished genome sequence and description of Bacillus massiliosenegalensis sp. nov. Stand Genomic Sci 2013; 8:264-278. PubMed http://dx.doi.org/10.4056/sigs.3496989

28. Ramasamy D, Lagier JC, Nguyen TT, Raoult D, Fournier PE. Non contiguous-finished genome sequence and description of Dielma fastidiosa gen. nov., sp. nov., a new member of the Family Erysipelotrichaceae. Stand Genomic Sci 2013; 8:336-351. PubMed http://dx.doi.org/10.4056/sigs.3567059

29. Mishra AK, Lagier JC, Robert C, Raoult D, Fournier PE. Genome sequence and description of Timonella senegalensis gen. nov., sp. nov., a new member of the suborder Micrococcinae. Stand Genomic Sci 2013; 8:318-335. PubMed http://dx.doi.org/10.4056/sigs.3476977

30. Collins MD, Smida J, Stackebrandt E. Phylogenetic Evidence for the Transfer of Caseobacter polymorphus (Crombach) to the Genus Corynebacterium. Int I Syst Evol Microbiol 1989; 39:7-9.

31. List of Prokaryotic names with Standing in Nomenclature. http://bacterio.net

32. Wagner KS, White JM, Lucenko I, Mercer D, Crowcroft NS, Neal S, Efstratiou A. Diphtheria in the postepidemic period, Europe, 2000-2009. Emerg Infect Dis 2012; 18:217-225. PubMed http://dx.doi.org/10.3201/eid1802.110987

33. Dias AA, Santos LS, Sabbadini PS, Santos CS, Silva Junior FC, Napoleão F, Nagao PE, Villas-Bôas $\mathrm{MH}$, Hirata Junior R, Guaraldi AL.

Corynebacterium ulcerans diphtheria: an emerging zoonosis in Brazil and worldwide. Rev Saude Publica 2011; 45:1176-1191. PubMed http://dx.doi.org/10.1590/S0034$\underline{89102011000600021}$

34. Gao B, Gupta RS. Phylogenetic framework and molecular signatures for the main clades of the phylum Actinobacteria . Microbiol Mol Biol Rev 2012; 76:66-112. PubMed http://dx.doi.org/10.1128/MMBR.05011-11

35. Field D, Garrity G, Gray T, Morrison N, Selengut J, Sterk P, Tatusova T, Thomson N, Allen MJ, Angiuoli SV, et al. The minimum information about a genome sequence (MIGS) specification. Nat Biotechnol 2008; 26:541-547. PubMed http://dx.doi.org/10.1038/nbt1360

36. Woese CR, Kandler O, Wheelis ML. Towards a natural system of organisms: proposal for the domains Archaea, Bacteria, and Eucarya. Proc Natl Acad Sci USA 1990; 87:4576-4579. PubMed http://dx.doi.org/10.1073/pnas.87.12.4576

37. Garrity GM, Holt JG. The road map to the manual. In Bergey's Manual ${ }^{\circledR}$ of Systematic Bacteriology 2011; 119-166. 
38. Stackebrandt E, Rainey FA, Ward-Rainey NL. Proposal for a New Hierarchic Classification System, Actinobacteria classis nov. Int I Syst Bacteriol 1997; 47:479-491. http://dx.doi.org/10.1099/00207713-47-2-479

39. Skerman VBD, McGowan V, Sneath PHA. Approved Lists of Bacterial Names. Int / Syst Bacteriol 1980; 30:225-420. http://dx.doi.org/10.1099/00207713-30-1-225

40. Zhi XY, Li WJ, Stackebrandt E. An update of the structure and 16S rRNA gene sequence-based definition of higher ranks of the class Actinobacteria, with the proposal of two new suborders and four new families and emended descriptions of the existing higher taxa. Int J Syst Evol Microbiol 2009; 59:589-608. PubMed http://dx.doi.org/10.1099/ijs.0.65780-0

41. Buchanan RE. Studies in the nomenclature and classification of bacteria. II. The primary subdivisions of the Schizomycetes. I Bacteriol 1917; 2:155-164. PubMed

42. Lehmann KB, Neumann R. Lehmann's Medizin, Handatlanten. X Atlas und Grundriss der Bakteriologie und Lehrbuch der speziellen bakteriologischen Diagnostik., Fourth Edition, Volume 2, J.F. Lehmann, München, 1907, p. 270.

43. Lehmann KB, Neumann R. Atlas und Grundriss der Bakteriologie und Lehrbuch der speziellen bakteriologischen Diagnostik, First Edition, J.F. Lehmann, München, 1896, p. 1-448.

44. Bernard KA, Wiebe D, Burdz T, Reimer A, Ng B, Singh C, Schindle S, Pacheco AL. Assignment of Brevibacterium stationis (ZoBell and Upham 1944) Breed 1953 to the genus Corynebacterium , as Corynebacterium stationis comb. nov., and emended description of the genus Corynebacterium to include isolates that can alkalinize citrate. Int J Syst Evol Microbiol 2010; 60:874-879. PubMed http://dx.doi.org/10.1099/ijs.0.012641-0

45. Ashburner M, Ball CA, Blake JA, Botstein D, Butler $\mathrm{H}$, Cherry JM, Davis AP, Dolinski K, Dwight SS, Eppig JT, et al. Gene ontology: tool for the unification of biology. The Gene Ontology Consortium. Nat Genet 2000; 25:25-29. PubMed http://dx.doi.org/10.1038/75556

46. Seng P, Drancourt M, Gouriet F, La Scola B, Fournier PE, Rolain JM, Raoult D. Ongoing revolution in bacteriology: routine identification of bacteria by matrix-assisted laser desorption ionization time-of-flight mass spectrometry. Clin Infect Dis 2009; 49:543-551. PubMed http://dx.doi.org/10.1086/600885

47. Field D, Garrity G, Gray T, Morrison N, Selengut J, Sterk P, Tatusova T, Thomson N, Allen MJ,
Angiuoli SV, et al. The minimum information about a genome sequence (MIGS) specification. Nat Biotechnol 2008; 26:541-547. PubMed http://dx.doi.org/10.1038/nbt1360

48. Prodigal. http://prodigal.ornl.gov

49. Benson DA, Karsch-Mizrachi I, Clark K, Lipman DJ, Ostell J, Sayers EW. GenBank. Nucleic Acids Res 2012; 40:D48-D53. PubMed http://dx.doi.org/10.1093/nar/gkr1202

50. Lowe TM, Eddy SR. tRNAscan-SE: a program for improved detection of transfer RNA genes in genomic sequence. Nucleic Acids Res 1997; 25:955-964. PubMed http://dx.doi.org/10.1093/nar/25.5.0955

51. Lagesen K, Hallin P, Rødland EA, Staerfeldt HH, Rognes T, Ussery DW. RNAmmer: consistent and rapid annotation of ribosomal RNA genes. Nucleic Acids Res 2007; 35:3100-3108. PubMed http://dx.doi.org/10.1093/nar/gkm160

52. Bendtsen JD, Nielsen H, von Heijne G, Brunak S. Improved prediction of signal peptides: SignalP 3.0. J Mol Biol 2004; 340:783-795. PubMed http://dx.doi.org/10.1016/j.jmb.2004.05.028

53. Krogh A, Larsson B, von Heijne G, Sonnhammer EL. Predicting transmembrane protein topology with a hidden Markov model: application to complete genomes. J Mol Biol 2001; 305:567580. PubMed http://dx.doi.org/10.1006/jmbi.2000.4315

54. Fischer D, Eisenberg D. Finding families for genomic ORFans. Bioinformatics 1999; 15:759-762. PubMed http://dx.doi.org/10.1093/bioinformatics/15.9.759

55. Zhou Y, Liang Y, Lynch KH, Dennis JJ, Wishart DS. PHAST: a fast phage search tool. Nucleic Acids Res 2011; 39:W347-W352. PubMed http://dx.doi.org/10.1093/nar/gkr485

56. Rutherford K, Parkhill J, Crook J, Horsnell T, Rice P, Rajandream MA, Barrell B. Artemis: sequence visualization and annotation. Bioinformatics 2000; 16:944-945. PubMed http://dx.doi.org/10.1093/bioinformatics/16.10.94 $\underline{4}$

57. Carver T, Thomson N, Bleasby A, Berriman M, Parkhill J. DNA Plotter: circular and linear interactive genome visualization. Bioinformatics 2009; 25:119-120. PubMed http://dx.doi.org/10.1093/bioinformatics/btn578

58. Lechner M, Findeiss S, Steiner L, Marz M, Stadler PF, Prohaska SJ. Proteinortho: detection of (co)orthologs in large-scale analysis. BMC Bioinformatics 2011; 12:124. PubMed http://dx.doi.org/10.1186/1471-2105-12-124 